\title{
Učinkovitost tehnika usredotočene svjesnosti i virtualne realnosti u smanjenju stresa te uloga osobine usredotočene svjesnosti i anksioznosti
}

\author{
Barbara Žuro \\ Peter McVerry Trust, Dublin, Ireland
}

\begin{abstract}
Sažetak
U posljednje vrijeme raste popularnost usredotočene svjesnosti i virtualne realnosti u kontekstu nošenja sa stresom. Usprkos tomu nema dovoljno istraživanja koja su uspoređivala te tehnike i uzimala u obzir osobine ličnosti. Cilj je ovoga istraživanja bio ispitati učinkovitost tehnike usredotočene svjesnosti i virtualne realnosti u neposrednome ublažavanju stresa te ispitati učinkovitost tehnika ovisno o individualnim razlikama u osobinama anksioznosti i usredotočene svjesnosti. Istraživanje je provedeno na 122 sudionika. Za izazivanje uznemirenosti korištena je oprema virtualne realnosti i animacija visine. U svrhu opuštanja korištena je tehnologija virtualne realnosti i animacija prirode te snimka usredotočene svjesnosti, a pratile su se subjektivne i fiziološke mjere uznemirenosti (elektrodermalna aktivnost). Za prikupljanje podataka o osobini usredotočene svjesnosti korišten je Petfaktorski skraćeni upitnik usredotočene svjesnosti, dok je za anksioznost korištena skala anksioznosti u Upitniku tendencija izbjegavanja i približavanja. Dobiveni rezultati pokazali su kako su sudionici procjenjivali nižu uznemirenost nakon izlaganja animaciji prirode i snimci usredotočene svjesnosti u odnosu na kontrolnu skupinu, dok fiziološke mjere nisu pratile takve rezultate. Nadalje, uz primjenu snimke najviše su se opustili visoko anksiozni i nisko usredotočeno svjesni pojedinci, dok u primjeni animacije prirode te osobine nisu igrale značajnu ulogu. Provedeno istraživanje ukazuje na mogućnost korištenja kratkih tehnika usredotočene svjesnosti i virtualne realnosti pri nošenju sa stresom te na važnost osobina ličnosti pri odabiru tehnike.
\end{abstract}

Ključne riječi: usredotočena svjesnost, virtualna realnost, anksioznost, elektrodermalna aktivnost

\section{Uvod}

Brojna istraživanja i teorije usmjereni su na različite načine pomoću kojih se ljudi suočavaju s teškoćama tijekom života. U posljednje se vrijeme sve više pažnje usmjerava na relativno nove tehnike i primjenu tehnologije u svrhu nošenja sa stresom. Velik broj istraživanja tako podupire mnoge dobrobiti sudjelovanja u

Barbara Žuro, Peter McVerry Trust, 29 Mountjoy Square, Dublin 1, Ireland. E-pošta: bzuro@pmvtrust.ie 
treninzima usredotočene svjesnosti (Carmody i Baer, 2008). Osim toga, sve se više prepoznaju potencijali tehnologija, kao što je primjerice virtualna realnost, u svrhu smanjenja stresa stvaranjem umirujuće okoline.

U dosadašnjim istraživanjima tehnika usredotočene svjesnosti korišteni su treninzi koji traju do nekoliko tjedana te je vrlo malo pažnje posvećivano primjeni kratkih tehnika bez prethodnoga uvježbavanja. Osim toga, gotovo da i nema informacija o tome koje su od tehnika učinkovitije ovisno o ličnosti pojedinca. Ovim se istraživanjem želi ispitati učinkovitost kratkih tehnika usredotočene svjesnosti i virtualne realnosti u neposrednome ublažavanju stresa te ispitati učinkovitost tehnika ovisno o individualnim razlikama u osobinama anksioznosti i usredotočene svjesnosti. Dodatan je doprinos istraživanja što se uz subjektivne procjene uznemirenosti prate i fiziološke mjere elektrodermalne aktivnosti, što će pružiti daljnje informacije o učincima korištenih tehnika.

\section{Stres i strategije suočavanja}

Prema suvremenim teorijama stresa potpuno objašnjenje moguće je promatranjem interakcije pojedinca i okoline. Najpoznatiji transakcijski model Lazarusa i suradnika stres promatra kao proces, a ne izdvojeni događaj. Najvažnija je komponenta Lazarusova pristupa pojam stresa kao rezultata procjene pojedinca o poremećenosti njegova odnosa s okolinom. Bez takve procjene nema ni stresa, neovisno o objektivnoj opasnosti (Lazarus i Folkman, 1984). U takvome se pristupu uglavnom koriste subjektivne procjene oslanjajući se na percepciju pojedinca (Christensen i sur., 2019). Utvrđivanje razine stresa odgovorom na pitanja ili procjenama na skali može se smatrati subjektivnim mjerama (Goyal i sur., 2016). S druge strane, objektivne mjere ne uzimaju u obzir percepciju pojedinca, već fiziološke odgovore. Jedna je od objektivnih mjera stresa elektrodermalna aktivnost - psihofiziološka mjera simpatičke aktivnosti autonomnoga živčanog sustava (Boucsein, 2012). Stres je povezan s povećanom razinom aktivacije u tijelu kada dominira simpatička aktivnost (Föhr i sur., 2015) te dolazi do porasta elektrodermalne aktivnosti. Kako subjektivne i objektivne mjere često ne mjere istu stvar (Hellhammer i Hellhammer, 2008), ovo će istraživanje koristiti obje mjere.

Dva su središnja koncepta za razumijevanje suočavanja sa stresom prilaženje i izbjegavanje. Prilaženje i izbjegavanje odnose se na temeljne orijentacije prema stresnim situacijama, odnosno na strategije suočavanja. Izbjegavanje se pokazalo korisnim u smanjenju stresa prije nego što preplavi pojedinca, posebice $\mathrm{u}$ nekontrolabilnim situacijama. S druge strane, prilaženje omogućuje odgovarajuću aktivnost, primjećivanje i iskorištavanje promjena u svoju korist (Roth i Cohen, 1986). Prilaženje se pokazalo korisnijim kada se prate dugotrajni učinci stresa (Mullen i Suls, 1982) te kada postoji mogućnost kontrole situacije. Različite situacije mogu zahtijevati različite strategije suočavanja. Usto, neke su osobe sklonije određenim strategijama bez obzira na zahtjeve situacije (Roth i Cohen, 1986). Sve 
navedeno strategije suočavanja čini kompleksnima, a razvijanje novih i pojedincu prilagođenih tehnika od iznimne je važnosti. U takvome se pristupu naglasak stavlja na procesiranje prijeteće informacije - hoće li se osoba usmjeriti na nju ili će je pokušati izbjeći. Čini se kako bi modificiranje usmjeravanja pažnje moglo igrati važnu ulogu u tome kontekstu. Ovo će se istraživanje usmjeriti na tehnike usredotočene svjesnosti koje zahtijevaju usmjeravanje pažnje na ono što se odvija u sadašnjemu trenutku te na korištenje virtualne realnosti koje se može rabiti kao distrakcija. U nacrtima dosadašnjih istraživanja sudionici su se upoznavali $\mathrm{s}$ određenom tehnikom prije njezine primjene. Ovim će se istraživanjem pokazati koliko su tehnike učinkovite bez uvježbavanja, neposredno nakon izlaganja stresoru. Dosadašnja su istraživanja uglavnom bila ograničena na pojedinačnu tehniku te nisu uzimala u obzir osobine ličnosti. Pretpostavlja se kako će važnu ulogu imati osobine usredotočene svjesnosti i anksioznosti jer je niz istraživanja ukazao na njihovu važnost u nošenju sa stresom (Tomlinson i sur., 2015).

\section{Tehnike usredotočene svjesnosti i virtualne realnosti}

O usredotočenoj svjesnosti može se govoriti kao o stanju koje se nastoji postići tijekom različitih vježbi usredotočene svjesnosti. Ono podrazumijeva povećano usmjeravanje pažnje na doživljaje koji se odvijaju u sadašnjosti na neprosuđujući i prihvaćajući način (Linehan, 1993). Osoba se potiče na uočavanje i prihvaćanje misli, osjećaja ili tjelesnih senzacija onakvih kakve jesu (Boričević-Maršanić i sur., 2015). Doživljavanje sadašnjega trenutka na neosuđujući način dozvoljava širu perspektivu u odnosu na misli koje se vide kao prolazne, na osjećaje koji se vide kao trenutno iskustvo i na tjelesne senzacije koje se vide kao odgovori tijela na trenutne osjećaje (Boričević-Maršanić i sur., 2015). Ovo se istraživanje usmjerilo i na virtualnu realnost koja se kao terapijska tehnika počela koristiti još 1992. godine te se pokazala učinkovitom u tretmanu različitih poremećaja (North i sur., 1997) i u smanjenju stresa. Thoondee i Oikonomou (2017) pokazali su kako korištenje virtualne realnosti doprinosi osjećaju opuštenosti te može dovesti do smanjenja stresa na poslu. Osim toga, priroda i zeleni okoliš pokazali su se učinkovitima u smanjenju stresa (Annerstedt i sur., 2013), a virtualna je realnost tehnologija koja omogućava stvaranje upravo takvih okoliša. U prošlosti se naglasak stavljao na statičke simulacije prirode, poput slika. Danas su mogućnosti mnogo veće te se korištenjem virtualne realnosti stvara dinamičnija alternativa s većom ekološkom valjanošću (de Kort i sur., 2003).

\section{Individualne razlike i reaktivnost na tehnike smanjenja stresa}

Za razliku od usredotočene svjesnosti kao vještine, osobina se usredotočene svjesnosti, bez intervencija, pokazala stabilnom tijekom vremena (Brown i Ryan, 2003). Jedna je od najpopularnijih konceptualizacija usredotočene svjesnosti ona Baera i suradnika (2008) koja u obzir uzima složenost svojstvenu originalnoj 
definiciji te se određuje kao tendencija osobe prema usredotočenome usmjeravanju pažnje na trenutne događaje, neosuđujućemu prihvaćanju događaja i samosuosjećanju. Osobe na višim razinama usredotočene svjesnosti sklonije su usredotočenomu i neosuđujućem usmjeravanju pažnje na svoje emocije. Moguće je kako će takvim osobama odgovarati tehnike smanjenja stresa usmjerene na prilaženje, odnosno tehnike koje uključuju neosuđujuće procesiranje informacije i kada je ta informacija neugodna. No osobe s izraženom usredotočenom svjesnošću sklonije su usmjeravati pažnju i na događaje u svojoj okolini (Lotten i sur., 2012). Takve bi osobe mogle bolje iskoristiti virtualna okruženja stvorena za opuštanje. S druge strane, anksiozne su osobe sklonije izbjegavanju emocija i neprihvaćanju svojih emocionalnih stanja (Hayes i sur., 2006) te su motiviranije za uključivanje u strategije emocionalne regulacije koje su usmjerene prema izbjegavajućoj funkciji (Hayes i sur., 1996). Nameće se pitanje koliko bi neuvježbane anksiozne osobe bile spremne prihvatiti tehnike usredotočene svjesnosti koje zahtijevaju usmjeravanje pažnje na emocije. Moguće je kako bi takvim osobama, barem na početku, više odgovarale distrakcije.

Cilj je ovoga istraživanja ispitati učinkovitost tehnike usredotočene svjesnosti i virtualne realnosti u neposrednome ublažavanju stresa te ispitati učinkovitost tehnika ovisno o individualnim razlikama $u$ osobinama anksioznosti i usredotočene svjesnosti. Istraživanja su pokazala dobrobiti tehnika usredotočene svjesnosti i virtualne realnosti u nošenju sa stresom, kao što su poboljšanje emocionalne regulacije (Shapiro i sur., 2006), psihofiziološka reaktivnost na stres (Brewer i sur., 2009) i smanjenje stresa na poslu (Thoondee i Oikonomou, 2017). Zbog toga se, kao dio prve hipoteze, pretpostavilo kako će tehnike usredotočene svjesnosti i virtualne realnosti rezultirati značajno nižim razinama uznemirenosti u odnosu na kontrolnu skupinu. Kao što je ranije opisano, osobe na višim razinama usredotočene svjesnosti sklonije su usredotočenomu i neosuđujućem usmjeravanju pažnje na svoje emocije i okolinu, dok su anksiozne osobe sklonije izbjegavanju emocija i neprihvaćanju svojih emocionalnih stanja. Zbog toga se, kao dio druge hipoteze, pretpostavilo kako će tehnika usredotočene svjesnosti biti učinkovitija kod osoba s visokim razinama usredotočene svjesnosti i niskim razinama anksioznosti, dok će virtualna realnost biti učinkovitija kod osoba koje su visoko na skalama anksioznosti i usredotočene svjesnosti.

\section{Metoda}

\section{Sudionici}

Uzorak su sačinjavale 122 osobe, pri čemu je 61 bila muškoga, a 61 ženskog spola. Zbog tehničkih se poteškoća broj sudionika razlikovao ovisno o tome koja je fiziološka mjera korištena. U nekoliko se sudionika prsten nije povezao s računalom 
te su se podatci izgubili. Starost sudionika kretala se od 19 do 45 godina $(M=22.82$, $S D=4.02$ ). Uzorak je sačinjavala 1 osoba sa završenom osnovnom školom, 77 osoba sa završenom srednjom školom, 27 osoba sa završenim preddiplomskim studijem te 16 osoba sa završenim diplomskim studijem.

\section{Instrumenti}

Petfaktorski skraćeni upitnik usredotočene svjesnosti (15-item Five-Facet Mindfulness Questionnaire; FFMQ-15; Baer i sur., 2012) namijenjen je mjerenju osobine usredotočene svjesnosti. Originalnu su verziju upitnika preveli Gračanin i suradnici (2017). Zbog kompleksnosti nacrta i opterećenosti sudionika za potrebe je ovoga istraživanja prevedena skraćena verzija upitnika. Upitnik se sastoji od 15 čestica i pet faktora, pri čemu se svaki faktor sastoji od triju čestica. Faktori su sljedeći: opažanje (Kada se tuširam ili kupam, obraćam pažnju na osjećaj vode na mome tijelu), opisivanje (Lako pronalazim riječi kojima bih opisao/la svoje osjećaje), djelovanje sa svjesnošću (Različite zadatke obavljam automatski $i$ nesvjesno), neprosuđivanje iskustva (Mislim kako su neki moji osjećaji loši ili neprimjereni i kako ih ne bih trebao/la osjećati) i nereagiranje na unutrašnje iskustvo (Kada mi se jave uznemirujuće misli ili predodžbe, samo ih primijetim i pustim da prođu). Odgovara se na skali Likertova tipa od pet stupnjeva, pri čemu 1 znači Nikada ili gotovo nikada, 5 Gotovo uvijek ili uvijek, a rezultat se formira kao suma odgovora. U ovome je radu korišten ukupni rezultat, a pouzdanost upitnika iznosi $\alpha$ $=.74$.

Upitnik tendencija izbjegavanja i približavanja (Questionnaire of Approach and Avoidance Motivation; QAAM; Krupić, Krupić i sur., 2020) upitnik je kojim se mjere četiri uže domene motivacije približavanja s četirima česticama po skali: ambicioznost (Htio/htjela bih biti važna osoba), poticajnost (Mogao/la bih reći za sebe da sam osoba sa širokim interesima), ustrajnost (Vrlo uporno i ustrajno radim sve dok ne dobijem ono što želim) i ugoda (Mene je lako razveseliti); te dvjema skalama izbjegavanja: anksioznost, koja se sastoji od 7 čestica (Osjećam se preplašeno pred važne događaje), te panika, s 4 čestice (Nekoliko puta sam ostao/la nepomično stajati uslijed velikoga osjećaja panike). Dvije skale izbjegavanja ukazuju na razliku između anksioznosti i straha. Čestice se procjenjuju na Likertovoj skali od šest stupnjeva, pri čemu 1 znači $U$ potpunosti se ne odnosi na mene, a $6 U$ potpunosti se odnosi na mene. Tijekom istraživanja koristila se skala anksioznosti, a pouzdanost skale iznosi $\alpha=.85$.

Moodmetric prsten uređaj je za mjerenje elektrodermalne aktivnosti (EDA). Senzori prstena detektiraju provodljivost kože tako što djeluju kao elektroda. MoodMetric rezultat (MM) na prstenu može se kretati od 1 do 100 , a viši rezultat podrazumijeva veću uzbuđenost. Prsten ima mali kapacitet za pohranu pa se podatci putem Bluetooth-veze prenose na računalo za trajno pohranjivanje. 
VR-oprema koristila se za izazivanje uznemirenosti i opuštanje. Pomoću VR-a HTC Vive sudionici su bili izloženi aplikaciji Richie's plank experience koja ih prikazuje na visini s ciljem izazivanja pobuđenosti. Oprema je uključivala naočale i ručnu palicu. Kako bi se povećala realnost animacije, korištena je daska dužine dva metra. Usto, korišten je i VR Oculus rift kako bi se sudionici izložili animaciji boravka u prirodi Nature TreksVR s ciljem snižavanja pobuđenosti. U tome je slučaju oprema uključivala naočale i upravljač za Xbox. Animacije se mogu pronaći na mrežnoj stranici Steam.

Snimka prostora disanja za stresne situacije korištena je kako bi se sudionici opustili. Na snimci koja traje 4 minute i 29 sekundi upute daje ženski glas. U prvome su dijelu snimke sudionici dobili uputu da se udobno smjeste i zaklope oči ili da gledaju u jednu točku te da usmjere pažnju na ono što se upravo događa s njihovim mislima, osjećajima i tjelesnim senzacijama. Nakon toga pažnja se usmjerava na tjelesne senzacije disanja i cijeloga tijela. Snimka se temelji na radu Segala i suradnika (2002) te Kabat-Zinna (2003).

Kako bi se ispitao strah od visine, sudionicima je dana sljedeća tvrdnja: „Molimo Vas da na sljedećoj skali označite koliko se bojite visine, pri čemu 1 označava uopće se ne bojim, dok 10 označava jako se bojim."

Subjektivna procjena stresa ispitivala se pomoću sljedeće tvrdnje: ,,Molimo Vas da na sljedećoj skali označite koliko ste trenutno uznemireni, pri čemu 1 znači uopće nisam uznemiren/a, dok 10 znači jako sam uznemiren/a."

Kako bi se provjerila uživljenost $\mathrm{u}$ animaciju, sudionicima je dana sljedeća tvrdnja: „Molimo Vas da na sljedećoj skali označite koliko ste se uspjeli uživjeti u VR-animaciju, pri čemu 1 označava nimalo, dok 10 označava u potpunosti.“

\section{Postupak}

Sudionici su regrutirani kreiranjem događaja na društvenoj mreži Facebook. U prvome su dijelu istraživanja sudionici rješavali upitnike. Drugi su dio istraživanja činile tri točke mjerenja. U prvoj se točki sudionicima mjerila EDA u stanju mirovanja te su odgovarali na pitanje koliko se boje visine i koliko su trenutno uznemireni. Neposredno nakon toga, u drugoj točki mjerenja, sudionicima je prikazana VR-animacija visine u kojoj su postavljeni ispred dizala. Sudionici dobivaju uputu da uđu u dizalo koje se potom podiže na gornji kat nebodera. Nakon što su sudionici stigli do gornjega kata nebodera, vrata se dizala otvaraju i sudionici mogu vidjeti dasku te dobivaju upute da hodaju dokraja daske i vrate se u dizalo. Tijekom hodanja po dasci mjerila se EDA. Nakon toga sudionici su odgovarali na pitanje koliko su uznemireni te koliko su se uspjeli uživjeti u animaciju. U trećoj su se točki mjerenja sudionici po slučaju dijelili u tri skupine. Jednoj je skupini puštena VR-animacija prirode. Drugoj je skupini putem mobilnoga telefona i slušalica puštena snimka US-a. Kontrolna je skupina dobila uputu da nekoliko minuta pričeka povratak eksperimentatora. Treća točka mjerenja slijedila je neposredno nakon druge 
te je u svim trima skupinama približno četiri minute mjerena EDA. Nakon toga sudionici su odgovarali na pitanje o uznemirenosti.

Istraživanje je odobrilo Etičko povjerenstvo Odsjeka za psihologiju Filozofskoga fakulteta u Osijeku.

\section{Rezultati}

Kolmogorov-Smirnovljevim testom utvrđeno je kako distribucije varijabli odstupaju od normalne te su izračunani indeksi asimetričnosti, koji su se kretali između -0.36 i 1.58, i indeksi spljoštenosti, između -0.97 i 6.11. Prema Klineu (2011) kriterij za normalnu distribuciju čine apsolutne vrijednosti te se distribucije mogu smatrati normalnima ako je indeks asimetričnosti manji od 3 , a indeks spljoštenosti manji od 8.

\section{Deskriptivna statistika}

Prosječna uživljenost u VR-animaciju visine iznosila je $M=8.44(S D=1.50)$ od maksimalnih 10 bodova, što upućuje na to da su sudionici animaciju doživjeli poprilično realnom. Prosječan strah od visine iznosio je $M=5.65(S D=2.73)$. Deskriptivna statistika za strah od visine po grupama, MM-rezultate i subjektivne procjene uznemirenosti prikazana je u Tablici 1. Korelacije i deskriptivna statistika za subjektivne i fiziološke mjere opuštenosti, skalu anksioznosti i Upitnik usredotočene svjesnosti po grupama prikazane su u Tablici 2. Prosječan rezultat na Upitniku usredotočene svjesnosti na razini cijeloga uzorka iznosio je $M=48.39$ (SD = 7.65), dok je kod Skale anksioznosti iznosio $M=22.01(S D=6.61)$.

Tablica 1.

Deskriptivna statistika za strah od visine po grupama, MM-rezultate $i$ subjektivne procjene uznemirenosti

\begin{tabular}{lccccccccc}
\hline & \multicolumn{2}{c}{ Kontrolna $(n=42)$} & \multicolumn{6}{c}{ Snimka US-a $(n=40)$} & \multicolumn{3}{c}{ VR-priroda $(n=40)$} \\
\cline { 2 - 9 } & Min. & Max. & $\begin{array}{c}M \\
(S D)\end{array}$ & Min. & Max. & $\begin{array}{c}M \\
(S D)\end{array}$ & Min. & Max. & $\begin{array}{c}M \\
(S D)\end{array}$ \\
\hline $\begin{array}{l}\text { Strah od } \\
\text { visine }\end{array}$ & 2.00 & 10.00 & $\begin{array}{c}5.76 \\
(2.40)\end{array}$ & 1.00 & 10.00 & $\begin{array}{c}5.53 \\
(2.95)\end{array}$ & 1.00 & 10.00 & $\begin{array}{c}5.65 \\
(2.89)\end{array}$ \\
\hline $\begin{array}{l}\text { MM - } \\
\text { mirovanje }\end{array}$ & 20.69 & 99.00 & $\begin{array}{c}51.76 \\
(20.49)\end{array}$ & 12.09 & 99.00 & $\begin{array}{c}50.13 \\
(22.34)\end{array}$ & 21.65 & 99.00 & $\begin{array}{c}51.23 \\
(19.52)\end{array}$ \\
\hline $\begin{array}{l}\text { MM - } \\
\text { visina }\end{array}$ & 15.81 & 99.00 & $\begin{array}{c}35.85 \\
(21.55)\end{array}$ & 13.03 & 98.00 & $\begin{array}{c}33.04 \\
(19.48)\end{array}$ & 13.31 & 99.00 & $\begin{array}{c}32.96 \\
(14.97)\end{array}$ \\
\hline $\begin{array}{l}\text { MM - } \\
\text { opuštanje }\end{array}$ & 15.00 & 99.00 & $\begin{array}{c}31.26 \\
(17.99)\end{array}$ & 9.33 & 96.54 & $\begin{array}{c}29.81 \\
(15.18)\end{array}$ & 15.00 & 99.00 & $\begin{array}{c}32.42 \\
(13.89)\end{array}$ \\
\hline
\end{tabular}




\begin{tabular}{lccccccccc}
\hline & \multicolumn{2}{c}{ Kontrolna $(n=42)$} & \multicolumn{6}{c}{ Eksperimentalna situacija } \\
\cline { 2 - 10 } & Min. & Max. & $\begin{array}{c}M \\
(S D)\end{array}$ & Min. & Max. & $\begin{array}{c}M \\
(S D)\end{array}$ & Min. & Max. & $\begin{array}{c}M \\
(S D)\end{array}$ \\
\hline $\begin{array}{l}\text { Subjektivna } \\
\text { procjena u } \\
\text { mirovanju }\end{array}$ & 1.00 & 8.00 & $\begin{array}{c}3.00 \\
(1.85)\end{array}$ & 1.00 & 8.00 & $\begin{array}{c}2.90 \\
(1.78)\end{array}$ & 1.00 & 7.00 & $\begin{array}{c}2.68 \\
(1.69)\end{array}$ \\
\hline $\begin{array}{l}\text { Subjektivna } \\
\text { procjena na } \\
\text { visini }\end{array}$ & 1.00 & 10.00 & $\begin{array}{c}4.93 \\
(2.69)\end{array}$ & 2.00 & 10.00 & $\begin{array}{c}5.23 \\
(2.66)\end{array}$ & 1.00 & 10.00 & 5.55 \\
\hline $\begin{array}{l}\text { Subjektivna } \\
\text { procjena u } \\
\text { opuštanju }\end{array}$ & 1.00 & 8.00 & $\begin{array}{c}3.55 \\
(2.23)\end{array}$ & 1.00 & 10.00 & $\begin{array}{c}2.43 \\
(2.15)\end{array}$ & 1.00 & 7.00 & $\begin{array}{c}1.78 \\
(1.19)\end{array}$ \\
\hline
\end{tabular}

Napomena: Min. - minimun; Max. - maksimum.: MM - MoodMetric rezultat; Snimka US-a - snimka usredotočene svjesnosti; VR-priroda - virtualna animacija prirode.

Tablica 2.

Korelacije i deskriptivna statistika za subjektivne mjere opuštenosti, fiziološke mjere opuštenosti, skalu anksioznosti i Upitnik usredotočene svjesnosti

\begin{tabular}{|c|c|c|c|c|c|c|c|c|c|c|c|c|}
\hline & \multicolumn{12}{|c|}{ Eksperimentalna situacija } \\
\hline & \multicolumn{4}{|c|}{ Kontrolna } & \multicolumn{4}{|c|}{ Snimka US-a } & \multicolumn{4}{|c|}{ VR-priroda } \\
\hline & 1 & 2 & 3 & 4 & 1 & 2 & 3 & 4 & 1 & 2 & 3 & 4 \\
\hline 1. & & & & & & & & & & & & \\
\hline $\begin{array}{l}\text { Subjektivna } \\
\text { mjera } \\
\text { opuštenosti }\end{array}$ & & -.15 & -.10 & .09 & & .04 & $.37^{*}$ & $-.40^{*}$ & & -.12 & -.19 & -.14 \\
\hline $\begin{array}{l}\text { 2. Fiziološka } \\
\text { mjera } \\
\text { opuštenosti }\end{array}$ & & & .10 & .09 & & & $-.37^{*}$ & -.12 & & & -.13 & -.12 \\
\hline $\begin{array}{l}3 . \\
\text { Skala } \\
\text { anksioznosti }\end{array}$ & & & & $-.41^{* *}$ & & & & $-.34^{*}$ & & & & $-.33^{*}$ \\
\hline $\begin{array}{l}4 . \\
\text { Upitnik } \\
\text { usredotočene } \\
\text { svjesnosti }\end{array}$ & & & & & & & & & & & & \\
\hline$M$ & 1.38 & 3.05 & 22.37 & 49.58 & 2.85 & 3.39 & 22.61 & 47.10 & 3.78 & 0.54 & 21.08 & 48.45 \\
\hline$S D$ & 1.96 & 9.70 & 6.67 & 7.56 & 2.87 & 12.79 & 6.62 & 7.16 & 2.47 & 7.50 & 6.60 & 8.19 \\
\hline
\end{tabular}

Napomena: Snimka US-a - snimka usredotočene svjesnosti; VR-priroda - virtualna animacija prirode. ${ }^{*} p<.05 ;{ }^{* *} p<.01$.

\section{Razine uznemirenosti u trima točkama mjerenja i razlike među grupama}

U slučaju kada su MM-rezultati zavisna varijabla, analizom varijance utvrđeno je kako postoji statistički značajna razlika između triju točaka mjerenja, $F(2,110)=$ $94.85, p<.05, \eta_{\text {partial }}^{2}=.46$. Interakcija se nije pokazala značajnom te se MMvrijednosti kroz točke mjerenja nisu mijenjale ovisno o grupi, $F(4,220)=.20, p>$ 
$.05, \eta_{\text {partial }}^{2}=.00$. Višestrukim usporedbama uz Bonferronijevu korekciju utvrđeno je kako se MM-rezultati u prvoj točki značajno razlikuju od MM-rezultata u drugoj i trećoj točki. Sudionici su postizali najvišu elektrodermalnu aktivnost u prvoj točki mjerenja. U drugoj točki došlo je do pada elektrodermalne aktivnosti te se u trećoj točki aktivnost nije značajno mijenjala. Višestrukim usporedbama uz Bonferronijevu korekciju utvrđeno je kako se fiziološke mjere uznemirenosti među grupama nisu razlikovale.

Slika 1.

MM-rezultati u trima točkama mjerenja

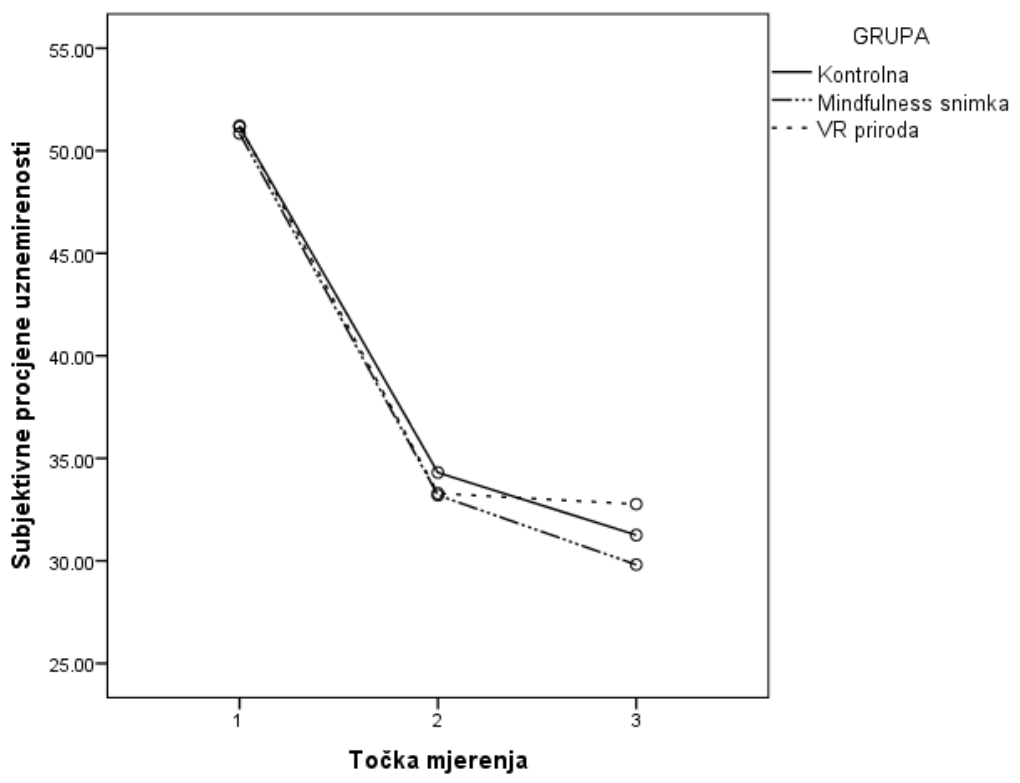

U slučaju subjektivnih procjena rezultati su pokazali statistički značajnu razliku između točaka mjerenja, $F(2,119)=91.45, p<.05, \eta_{\text {partial }}^{2}=.44$. Također, dobivena je statistički značajna interakcija, $F(4,238)=5.34, p<.05, \eta^{2}$ partial $=.08$. Proveden je Games-Howellov post-hoc test te je utvrđeno kako se subjektivne procjene u prvoj točki značajno razlikuju od onih u drugoj te kako se subjektivne procjene u drugoj točki značajno razlikuju od procjena $\mathrm{u}$ trećoj. Na temelju aritmetičkih sredina $\mathrm{u}$ Tablici 1. može se vidjeti kako su se sudionici procjenjivali najuznemirenijima $\mathrm{u}$ drugoj točki. Nakon toga su se u trećoj točki procjenjivali značajno manje uznemirenima. U kontrolnoj je grupi došlo do najmanjega pada uznemirenosti te se vrijednosti nisu približile onima iz prve točke, kao što je to bilo u eksperimentalnim grupama. Games-Howellovim post-hoc testom utvrđeno je kako se subjektivne procjene uznemirenosti značajno razlikuju između kontrolne grupe i eksperimentalnih grupa, dok među eksperimentalnim grupama razlika nije značajna. 
Slika 2.

Subjektivne procjene u trima točkama mjerenja

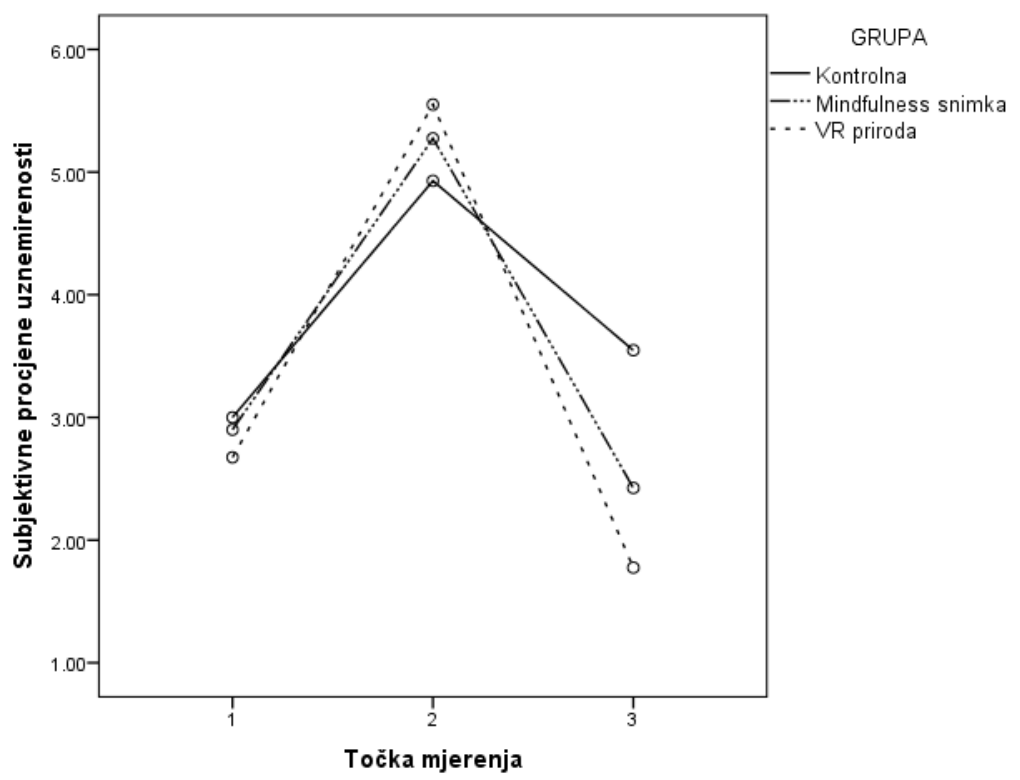

U slučaju fizioloških mjera razina uznemirenosti bila je podjednaka bez obzira na to je li sudionicima prikazana VR-animacija prirode, je li im puštena snimka ili su samo čekali. Suprotno tomu sudionici kojima je prikazana VR-animacija ili snimka sami su procjenjivali kako su značajno manje uznemireni u odnosu na sudionike koji su čekali. Prva je hipoteza potvrđena u slučaju subjektivnih mjera opuštenosti, dok u slučaju fizioloških nije.

\section{Mjera opuštenosti}

Kako bi se u daljnjoj obradi rezultata u obzir uzela promjena uznemirenosti sudionika, od druge do treće točke mjerenja izračunane su dvije mjere: fiziološka i subjektivna mjera opuštenosti. Fiziološka mjera opuštenosti računala se kao razlika između MM-rezultata u drugoj i MM-rezultata u trećoj točki mjerenja, a subjektivna mjera opuštenosti računala se kao razlika samoprocjena uznemirenosti u drugoj i trećoj točki mjerenja (Tablica 2.).

\section{Učinkovitost tehnika ovisno o osobinama usredotočene svjesnosti i anksioznosti}

Kako bi se provjerila druga hipoteza, korišten je Hayes Process programski dodatak SPSS-u. Zbog maloga broja sudionika nije provedena multikategorijalna moderatorska analiza s dvama moderatorima (model 3). Složeniji modeli zahtijevaju 
veće uzorke te neki autori smatraju kako bi za takvu analizu bilo potrebno barem 30 sudionika po potkategoriji (Sekaran, 2003). Provedene su odvojene moderatorske analize za prediktor usredotočene svjesnosti i za prediktor anksioznosti (model 1). U obama je slučajevima moderator-varijablu predstavljala grupa kojoj su sudionici pripadali, dok se kao kriterij koristila fiziološka i subjektivna mjera opuštenosti.

Model s fiziološkom mjerom i prediktorom usredotočene svjesnosti nije se pokazao statistički značajnim, $F(5,107)=.84, p>.05$. Također, statistička značajnost nije utvrđena ni $\mathrm{u}$ modelu $\mathrm{s}$ fiziološkom mjerom i prediktorom anksioznosti, $F(5,106)=1.78, p>.05$. U slučaju subjektivnih mjera oba su se modela pokazala statistički značajnima. Kada se kao prediktor koristila varijabla usredotočene svjesnosti, model je objasnio $20 \%$ variranja subjektivnih mjera opuštenosti, $F(5,114)=5.82, p<.05, R=.45, R^{2}=.20$. U Tablici 3. može se vidjeti kako su $t$-vrijednosti za W1 i W2 statistički značajne. Povezanosti subjektivnih mjera opuštenosti i usredotočene svjesnosti razlikuju se ovisno o grupi kojoj su sudionici pripadali. Nadalje, dobivena je statistički značajna interakcija između W1 i usredotočene svjesnosti. Prediktor te interakcije između W2 i usredotočene svjesnosti nije se pokazao statistički značajnim. Sudionici su se, neovisno o razinama usredotočene svjesnosti, u najvećoj mjeri opustili tijekom VR-animacije prirode te su se u nižim mjerama opuštali u kontrolnoj skupini. Suprotno tomu, u slučaju snimke US-a, subjektivne su mjere ovisile o razinama usredotočene svjesnosti sudionika. U najvećoj su se mjeri opustili sudionici s najnižim razinama usredotočene svjesnosti. Kako se povećava razina usredotočene svjesnosti, tako snimka US-a gubi učinkovitost. Kod sudionika s najvišim razinama usredotočene svjesnosti snimka je učinkovita kao i čekanje kontrolne skupine.

Slika 3.

Subjektivna mjera opuštenosti ovisno o usredotočenoj svjesnosti i pripadnosti grupi

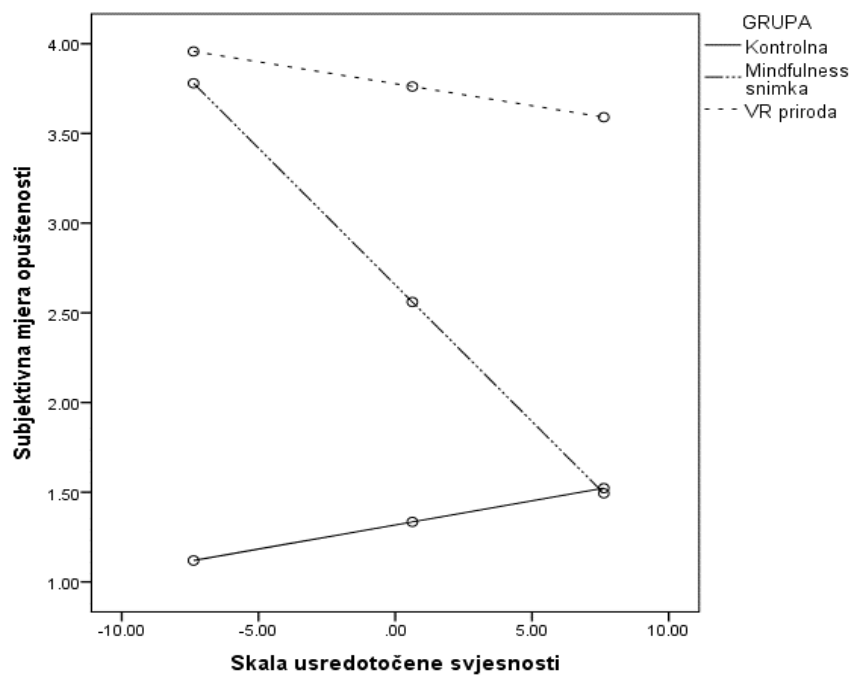


U drugome je modelu kao prediktor korištena mjera anksioznosti. Taj se model pokazao statistički značajnim, $F(5,113)=5.56, p<.05$, te objašnjava $20 \%$ varijance, $R=.44, R^{2}=.20$. Utvrđeno je kako anksioznost nije značajan prediktor, dok su $t$ vrijednosti za W1 i W2 statistički značajne (Tablica 3.). Stoga se povezanosti subjektivnih mjera opuštenosti i anksioznosti razlikuju ovisno o grupi kojoj su sudionici pripadali. Također, utvrđena je statistički značajna interakcija između W1 i anksioznosti. U slučaju VR-animacije sudionici su se u najvećoj mjeri opustili te su mjere opuštenosti približno jednake neovisno o razinama anksioznosti. Isto tako, sudionici su se u svakome slučaju najmanje opustili u kontrolnoj grupi. S druge strane, u slučaju snimke US-a visoko anksiozni pojedinci postigli su najveću subjektivnu mjeru opuštenosti. Kako se smanjuje anksioznost, tako se smanjuje mjera opuštenosti. U skupini s najnižom razinom anksioznosti, mjera opuštenosti nakon snimke US-a gotovo se izjednačila s opuštenošću sudionika kontrolne grupe. Dakle, razina anksioznosti sudionika utjecala je na konačnu mjeru opuštenosti kada je sudionicima puštena snimka US-a. Ni u jednome od obaju modela nisu dobiveni očekivani rezultati te se druga hipoteza nije potvrdila.

Slika 4.

Subjektivna mjera opuštenosti ovisno o anksioznosti i pripadnosti grupi

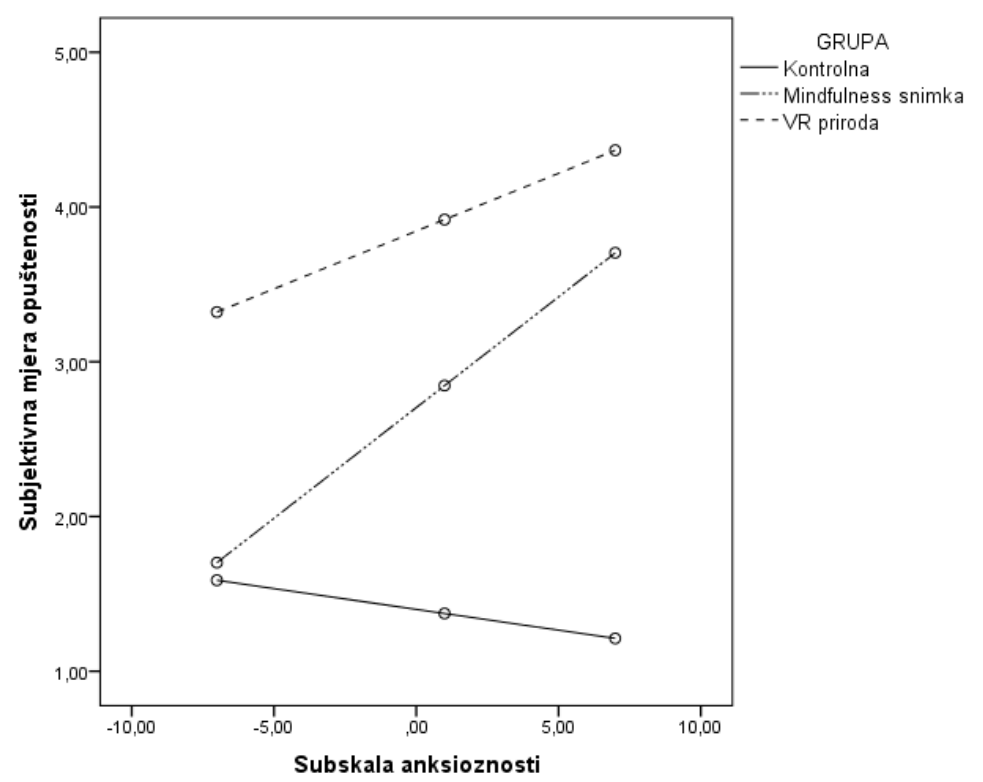


Žuro, B.:

Učinkovitost tehnika usredotočene svjesnosti $i$ virtualne realnosti

Tablica 3.

Moderatorska regresijska analiza za kriterij subjektivne mjere opuštenosti

\begin{tabular}{|c|c|c|c|c|c|c|c|}
\hline \multicolumn{4}{|c|}{ Upitnik usredotočene svjesnosti } & \multicolumn{4}{|c|}{ Skala anksioznosti } \\
\hline & $B$ & $S E$ & $t$ & & $B$ & $S E$ & $t$ \\
\hline Konstanta & 1.32 & .39 & $3.41^{* *}$ & Konstanta & 1.40 & .38 & 3.73 $^{\text {*** }}$ \\
\hline $\begin{array}{l}\text { Upitnik } \\
\text { usredotočene } \\
\text { svjesnosti }\end{array}$ & 0.03 & .05 & 0.53 & $\begin{array}{l}\text { Upitnik } \\
\text { anksioznosti }\end{array}$ & -0.03 & .06 & -0.47 \\
\hline W1 & 1.34 & .55 & $2.44^{*}$ & W1 & 1.30 & .54 & 2.41* \\
\hline W2 & 2.46 & .54 & $4.53^{* *}$ & W2 & 2.44 & .54 & $4.56^{*}$ \\
\hline $\begin{array}{l}\text { Upitnik } \\
\text { usredotočene } \\
\text { svjesnosti x W1 }\end{array}$ & -0.18 & .07 & $-2.41^{* * *}$ & $\begin{array}{l}\text { Upitnik } \\
\text { anksioznosti } \\
\text { x W1 }\end{array}$ & 0.17 & .08 & $2.06^{*}$ \\
\hline $\begin{array}{l}\text { Upitnik } \\
\text { usredotočene } \\
\text { svjesnosti x W2 }\end{array}$ & -0.05 & .07 & -0.74 & $\begin{array}{l}\text { Upitnik } \\
\text { usredotočene } \\
\text { svjesnosti x W2 }\end{array}$ & 0.10 & .09 & 1.25 \\
\hline
\end{tabular}

Napomena: $B$ - nestandardizirani beta koeficijent; $S E$ - standardna pogreška; W1 - snimka usredotočene svjesnosti u odnosu na virtualnu animaciju prirode i kontrolnu grupu; W2 - virtualna animacija prirode u odnosu na snimku usredotočene svjesnosti i kontrolnu grupu. ${ }^{*} p<.05 . ;{ }^{* *} p<.01$.

\section{Rasprava}

\section{Fiziološki i subjektivni pokazatelji uznemirenosti}

Kako bi se ispitala učinkovitost tehnika u nošenju sa stresom, sudionike je trebalo izložiti određenomu stresoru te je u tu svrhu korištena virtualna animacija visine. Ranija istraživanja ukazala su na to da se virtualne animacije visine mogu koristiti za izazivanje različitih znakova uznemirenosti (Gromer i sur., 2018). Tijekom izloženosti animaciji visine EDA se smanjila te su sudionici postizali vrijednosti koje se obično javljaju u opuštajućim situacijama. Moguće je kako je visina kod sudionika izazvala reakciju blokiranja koja podrazumijeva dominaciju parasimpatičkoga sustava, smanjenje pulsa (Walker i Carrive, 2003), pokretljivosti (Fanselow, 1994), promjene temperature tijela (Hagenaars i sur., 2014) te smanjenje elektrodermalne aktivnosti (Krupić i sur., 2020). Takva je reakcija u skladu sa subjektivnim procjenama jer su sudionici procjenjivali kako su se uznemirili tijekom izloženosti virtualnoj visini. Stoga se eksperimentalna manipulacija pokazala uspješnom, a VR adekvatnim instrumentom za izazivanje uznemirenosti.

Može se uočiti kako postoji neusklađenost između fizioloških i subjektivnih mjera. Problem izostanka kovarijance psiholoških i bioloških mjera poznat je desetljećima. Moguće je objašnjenje postojanje različitih vrsta odgovora na stresore pa mozak, ovisno o odgovoru, procesira stresore na različitim razinama svjesnosti. Izloženost je umirujućoj VR-animaciji prirode kod sudionika mogla potaknuti kognitivne procese poput sjećanja i asocijacija na prethodna opuštajuća iskustva. 
Takav odgovor na stres uglavnom ne uključuje kortikalne strukture te se može odvojiti od fiziološkoga odgovora (Hellhammer i Hellhammer, 2008). Prema tome, sudionici su mogli uočiti subjektivnu opuštenost tijekom izloženosti animaciji bez istodobnih fizioloških odgovora.

\section{Učinkovitost primijenjenih tehnika i uloga ličnosti}

\section{Snimka usredotočene svjesnosti}

Na razini grupe došlo je do smanjenja osjećaja uznemirenosti nakon slušanja snimke US-a. Postoji nekoliko mogućih objašnjenja zašto je snimka US-a rezultirala nižim procjenama uznemirenosti. Sam čin usmjeravanja na disanje obično usporava i produbljuje disanje (Western i Patrick, 1988), što potiče osjećaj smirenosti (KabatZinn, 1994). Snimka korištena u ovome istraživanju uključivala je uputu za poticanje sporijega i dubljeg disanja, što je moglo doprinijeti nižim procjenama uznemirenosti. Osim toga, sudionici su dobili uputu da prihvate neugodne emocije, misli ili tjelesne senzacije. Istraživanja su pokazala kako pokušaji izravne kontrole neugodnih emocija mogu imati negativne posljedice (Gratz i Tull, 2010). Wolgast i suradnici (2011) proveli su istraživanje u kojemu su sudionicima prikazali emocionalno pobuđujuće isječke filmova. Sudionici koji su dobili uputu da prihvate emocije koje se pojave izvijestili su o nižim razinama stresa. Moguće je kako je informacija o tome da je u redu osjetiti i prihvatiti negativne emocije doprinijela opuštenosti sudionika i u ovome istraživanju.

No osobine usredotočene svjesnosti i anksioznosti pokazale su se važnima za učinkovitost snimke US-a. Utvrdilo se kako su se pomoću snimke najmanje opustile visoko usredotočeno svjesne osobe, dok su se najviše opustili nisko usredotočeno svjesni pojedinci. Rezultati su iznenađujući jer su dosadašnja istraživanja pokazala kako pojedinci s izraženijom osobinom usredotočene svjesnosti imaju najviše dobrobiti od treninga usredotočene svjesnosti (Shapiro i sur., 2010). Nadalje, osobina usredotočene svjesnosti podrazumijeva spremnost za neosuđujuće prihvaćanje događaja, samosuosjećanje i usredotočeno usmjeravanje pažnje, a sve se navedeno od sudionika tražilo kroz snimku US-a. Postoji moguće objašnjenje takvih dobivenih rezultata. Glavni cilj primjene tehnika usredotočene svjesnosti nije opuštanje, već neosuđujuće prihvaćanje trenutnih misli, osjećaja i senzacija. Iako se opuštanje obično upravo zbog toga postiže, ono ne mora biti nužan ishod. Moguće je kako su visoko usredotočeno svjesni pojedinci uspješno pratili upute te su prepoznali svoju uznemirenost, ali četiri minute nisu bile dovoljne za opuštanje. Zanimljivo je da su se najviše opustile nisko usredotočeno svjesne osobe. Možda ti sudionici nisu uspjeli prepoznati uznemirenost te su neki drugi elementi snimke, poput usporenoga disanja, doprinijeli opuštanju.

Kada se promatrala osobina anksioznosti, pokazalo se kako su se najviše opustili visoko anksiozni pojedinci. Takvi rezultati nisu u skladu s očekivanjima jer su dosadašnja istraživanja pokazala kako su anksiozni pojedinci motiviraniji za 
uključivanje u izbjegavajuće strategije (Hayes i sur., 1996). Međutim, postoje istraživanja koja su pokazala kako su programi usredotočene svjesnosti uspješni u slučaju visoko anksioznih pojedinaca i različitih anksioznih poremećaja (Vøllestad i sur., 2011). Čini se kako visoko anksiozni pojedinci mogu smanjiti uznemirenost nakon primjene samo jedne tehnike. S druge strane, tehnika se pokazala najmanje učinkovitom kod nisko anksioznih pojedinaca. Manje anksiozni pojedinci obično preferiraju aktivnije strategije suočavanja (Folkman i Moskowitz, 2004), no oni rjeđe doživljavaju različite znakove anksioznosti. Moguće je da takvi sudionici nisu imali potrebu ni želju za izlaganjem novim tehnikama, za razliku od anksioznijih pojedinaca koji bi od njih mogli imati više koristi.

\section{VR-animacija}

Smanjenje osjećaja uznemirenosti nakon izloženosti animaciji prirode u skladu je s očekivanjima. Kao što je navedeno, istraživanja su pokazala kako se VR može uspješno koristiti za izazivanje različitih emocija i osjećaja opuštenosti (Riva i sur., 2007).

Moguće je da je VR-animacija imala učinke kao pozitivna ili neutralna distrakcija. Nakon stresora sudionici su se izložili novomu okuženju, što im je moglo zaokupiti pažnju. Istraživanja su pokazala kako pozitivne i neutralne distrakcije smanjuju aktivnost područja mozga povezanoga sa strahom i stresom (Ressler, 2010). Pozitivne distrakcije rezultiraju ugodnim emocijama koje mogu djelovati kao signal sigurnosti. Neki autori smatraju kako su se ugodne emocije razvile tijekom evolucije kao signali odsustva neposredne opasnosti (Gervais i Wilson, 2005). Ako je animacija djelovala kao pozitivna distrakcija, mogla je izazvati ugodne emocije te potaknuti istraživanje virtualnoga okruženja.

Nadalje, u animaciji je prikazana priroda te zvukovi karakteristični za takvo okruženje koji su se u nekoliko istraživanja povezali sa smanjenjem stresa. Diette i suradnici (2003) pokazali su kako slike prirode, uz zvukove prirode, mogu smanjiti uznemirenost tijekom bolnih pregleda. Ako su se samo slike i zvukovi prirode pokazali učinkovitima za smanjenje anksioznosti, može se pretpostaviti kako će virtualno simulirana okolina pokazati još veće efekte jer je sličnija stvarnoj životnoj situaciji. Ono što dodatno doprinosi tomu mogućnost je kretanja kroz virtualno okruženje, što je moglo pobuditi znatiželju i potaknuti istraživanje. Tijekom evolucije razvila se preferencija za specifične vrste okoliša. Jedna od preferencija tajnoviti su okolišs s krivudavim putovima i brežuljcima koji obećavaju da nešto leži iza njih (Buss, 2012). Priroda koja je prikazana pomoću VR-a odgovara upravo takvim preferencijama. Uz zvukove prirode sudionici su mogli čuti i opuštajuću glazbu koja se u ranijim istraživanjima pokazala učinkovitom tehnikom za smanjenje anksioznosti (Robb, 2000).

Prilikom primjene te tehnike osobine nisu imale utjecaj na razinu učinkovitosti. Iako su istraživanja pokazala kako pojedinci obično preferiraju određene strategije, ne može se reći kako uvijek koriste iste. Svi povremeno koriste različite strategije, a 
preferencije određuju njihovu frekvenciju (Roth i Cohen, 1986). Moguće je da je vrsta situacije imala veći utjecaj na učinkovitost tehnike od ispitivanih osobina ličnosti. Sheppes i Gross (2011) utvrdili su kako su distrakcije najkorisnije i preferiranije neposredno nakon nekoga neugodnog iskustva. U ovome su istraživanju sudionici bili izloženi korištenim tehnikama neposredno nakon stresora. Moguće je da je zbog toga sudionicima odgovaralo jednostavno preusmjeravanje pažnje na ugodnije podražaje.

Konačno, zbog povezanosti osobina usredotočene svjesnosti i anksioznosti moguće je da su nekim dijelom slični faktori utjecali na rezultate.

\section{Zaključak}

Ovo istraživanje ima nekoliko nedostataka. Nije prikupljen dovoljan broj sudionika te je izgubljena informacija o tome kako bi model izgledao kada bi se osobina usredotočene svjesnosti i anksioznosti uključile istodobno. Također, s obzirom na različite reakcije na stres, u budućim istraživanjima bilo bi dobro uključiti mjeru parasimpatičkoga sustava kako bi se dobila potpunija slika o fiziološkim promjenama te ispitati djeluje li VR kao neutralna ili pozitivna distrakcija. Usto, istovremeno su se primijenili vizualni podražaji, zvukovi prirode i opuštajuća glazba te nije jasno doprinose li svi ti elementi opuštanju. Konačno, potrebno je replicirati istraživanje na kliničkome uzorku.

Ovo je istraživanje ukazalo na korisnost tehnika usredotočene svjesnosti i virtualne realnosti u smanjenju stresa, ali i na važnost osobina ličnosti pri odabiru odgovarajućih tehnika. VR se pokazala učinkovitom tehnikom kod svih sudionika, što ukazuje na široke mogućnosti primjene te tehnike u svrhu smanjenja stresa. S druge strane, osobine ličnosti pokazale su se važnima za učinkovitost snimke usredotočene svjesnosti. S obzirom na rezultate, kratka i jednokratna tehnika usredotočene svjesnosti može se uspješno primjenjivati na visoko anksioznim i nisko usredotočeno svjesnim pojedincima.

\section{Literatura}

Annerstedt, M., Jönsson, P., Wallergård, M., Johansson, G., Karlson, B., Grahn, P., Hansen, A. M. i Währborg, P. (2013). Inducing physiological stress recovery with sounds of nature in a virtual reality forest - Results from a pilot study. Physiology \& Behavior, 118, 240-250. https://doi.org/10.1016/j.physbeh.2013.05.023

Baer, R. A., Carmody, J. i Hunsinger, M. (2012). Weekly change in mindfulness and perceived stress in a mindfulness-based stress reduction program. Journal of Clinical Psychology, 68(7), 755-765. https://doi.org/10.1002/jclp.21865 
Baer, R., Smith, G. T., Lykins, E., Button, D., Krietemeyer, J., Sauer, S., Walsh, E., Duggan, D. i Williams, J. M. G. (2008). Construct validity of the Five Facet Mindfulness Questionnaire in meditating and nonmeditating samples. Assessment, 15, 329-342. https://doi.org/10.1177/1073191107313003

Boričević-Maršanić, V., Paradžik, Lj., Zečević, I. i Karapetrić-Bolfan, Lj. (2015). Usredotočena svjesnost - mindfulness: Primjena u djece i adolescenata. Socijalna psihijatrija, 43, 142-150.

Boucsein, W. (2012). Electrodermal activity (2nd ed.). Springer.

Brewer, J. A., Sinha, R., Chen, J. A., Michalsen, R. N., Babuscio, T. A., Nich, C., Grier, A., Bergquist, K. L., Reis, D. L., Potenza, M. N., Carroll, K. M. i Rounsaville, B. J. (2009). Mindfulness training and stress reactivity in substance abuse: Results from a randomized, controlled stage I pilot study. Substance Abuse, 30(4), 306-317. https://doi.org/10.1080/08897070903250241

Brown, K.W. i Ryan, R.M. (2003). The Benefits of Being Present: Mindfulness and its role in psychological well-being. Journal of Personality and Social Psychology, 84(4), 822848. https://doi.org/10.1037/0022-3514.84.4.822

Buss, D. M. (2012). Evolucijska psihologija - Nova znanost o umu. Naklada Slap.

Carmody, J. i Baer, R. A. (2008). Relationships between mindfulness practice and levels of mindfulness, medical and psychological symptoms and well-being in a mindfulnessbased stress reduction program. Journal of Behavioral Medicine, 31, 23-33. https://doi.org/10.1007/s10865-007-9130-7

Christensen, D. S., Dich, N., Flensborg-Madsen, T., Garde, E., Hansen, Å. M. i Mortensen, E. L. (2019). Objective and subjective stress, personality, and allostatic load. Brain and Behavior, 9(9), e01386. https://doi.org/10.1002/brb3.1386

de Kort, Y. A. W., IJsselsteijn, W. A., Kooijman, J. i Schuurmans, Y. (2003). Virtual laboratories: Comparability of real and virtual environments for environmental psychology. Presence, Teleoperators and Virtual Environments, 12, 360-373.

Diette, G. B., Lechtzin, N., Haponik, E., Devrotes, A. i Rubin, H. R. (2003). Distraction therapy with nature sights and sounds reduces pain during flexible bronchoscopy: A complementary approach to routine analgesia. Chest, 123(3), 941-948. https://doi.org/10.1378/chest.123.3.941

Fanselow, M. S. (1994). Neural organization of the defensive behavior system responsible for fear. Psychonomic Bulletin \& Review, 1, 429-438. https://do.org/10.3758/BF03210947

Föhr, T., Tolvanen, A., Myllymäki, T., Järvelä-Reijonen, E., Rantala, S., Korpela, R., Peuhkuri, K., Kolehmainen, M., Puttonen, S., Lappalainen, R., Rusko, H. i Kujala, U. M. (2015). Subjective stress, objective heart rate variability-based stress, and recovery on workdays among overweight and psychologically distressed individuals: A crosssectional study. Journal of Occupational Medicine and Toxicology, 10, 39. https://doi.org/10.1186/s12995-015-0081-6

Folkman, S. i Moskowitz, J. T. (2004). Coping: Pitfalls and promise. Annual Review of Psychology, 55, 745-774. https://doi.org/10.1146/annurev.psych.55.090902.141456 
Gervais, M. i Wilson, D. S. (2005). The evolution and functions of laughter and humor: A synthetic approach. The Quarterly Review of Biology, 80(4), 395-430. https://doi.org/10.1086/498281

Goyal, A., Singh, S., Vir, D. i Pershad, D. (2016). Automation of stress recognition using subjective or objective measures. Psychological Studies, 61, 348-364. https://doi.org/10.1007/s12646-016-0379-1

Gračanin, A., Gunjača, V., Tkalčić, M., Kardum, I., Bajšanski, I. i Perak, B. (2017). Struktura usredotočene svjesnosti i njezina povezanost s crtama ličnosti i emocionalnim reagiranjem. Psihologijske teme, 26(3), 675-700. https://doi.org/10.31820/pt.26.3.9

Gratz, K. i Tull, M. (2010). The relationship between emotion dysregulation and deliberate self-harm among inpatients with substance use disorders. Cognitive Therapy and Research, 34, 544-553. https://doi.org/10.1007/s10608-009-9268-4

Gromer, D., Madeira, O., Gast, P., Nehfischer, M., Jost, M., Müller, M., Mühlberger, A. i Pauli, P. (2018). Height simulation in a virtual reality CAVE system: Validity of fear responses and effects of an immersion manipulation. Frontiers in Human Neuroscience, 12, 372. https://doi.org/10.3389/fnhum.2018.00372

Hagenaars, M. A., Oitzl M. i Roelofs, K. (2014). Updating freeze: Aligning animal and human research. Neuroscience \& Biobehavioral Reviews, 47, 165-176. https://doi.org/10.1016/ j.neubiorev.2014.07.021

Hayes, S. C., Luoma, J. B., Bond, F. W., Masuda, A. i Lillis, J. (2006). Acceptance and commitment therapy: Model, processes, and outcomes. Behaviour Research and Therapy, 44, 1-25. https://doi.org/10.1016/j.brat.2005.06.006

Hayes, S. C., Wilson, K. G., Gifford, E. V., Follette, V. M. i Strosahl, K. (1996). Experiential avoidance and behavioral disorders: A functional dimensional approach to diagnosis and treatment. Journal of Consulting and Clinical Psychology, 64, 1152-1168. https://doi.org/10.1037//0022-006x.64.6.1152

Hellhammer, D. H. i Hellhammer, J. (Ur.). (2008). Stress. The brain-body connection. Karger publishers.

Kabat-Zinn, J. (1994). Wherever you go, there you are: Mindfulness meditation in everyday life. Hyperion.

Kabat-Zinn, J. (2003) Mindfulness-Based Stress Reduction (MBSR). Constructivism in Human Sciences, 8(2), 73-107.

Kline, P. (2011). The handbook of psychological testing (2nd ed.). Routledge.

Krupić, D., Žuro, B. i Corr, P. (2020). Anxiety and threat magnification in subjective and physiological responses of fear of heights induced by virtual reality. Personality and Individual differences. Online publikacija. https://doi.org/10.1016/j.paid.2019.109720

Krupić, D., Krupić, D. i Corr, P. (2020). Questionnaire of Approach and Avoidance Motivation: Development and validation. U pripremi.

Lazarus R. S. i Folkman S. (1984). Stress, appraisal, and coping. Springer.

Linehan, M. M. (1993). Cognitive-behavioral treatment of borderline personality disorder. Guilford. 
Lotten, J. L., Lundh, L. G., Josefsson, T. i Falkenström, F. (2012). Observing as an essential facet of mindfulness: A comparison of FFMQ patterns in meditating and nonmeditating individuals. Mindfulness, 4, 1-10. https://doi.org/10.1007/s12671-0120111-8

Mullen, B. i Suls, J. (1982). The effectiveness of attention and rejection as coping styles. Journal of Psychosomatic Research, 26, 43-49. https://doi.org/10.1016/00223999(82)90061-7

North, M. M., North, S. M. i Coble, J. R. (1997). Virtual reality therapy: An effective treatment for psychological disorders. U: G. Riva (Ur.), Studies in health technology and informatics. Virtual reality in neuro-psycho-physiology: Cognitive, clinical and methodological issues in assessment and rehabilitation (str. 59-70). IOS Press.

Ressler, K. J. (2010). Amygdala activity, fear, and anxiety: Modulation by stress. Biological Psychiatry, 67(12), 1117-1119. https://doi.org/10.1016/j.biopsych.2010.04.027

Riva, G., Mantovani, F., Capideville, C. S., Preziosa, A., Morganti, F., Villani, D., Gaggioli, A., Botella, C. i Alcañiz, M. (2007). Affective interactions using virtual reality: The link between presence and emotions. CyberPsychology \& Behavior, 10(1), 45-56. https://doi.org/10.1089/cpb.2006.9993

Robb, S. L. (2000). Music assisted progressive muscle relaxation, progressive muscle relaxation, music listening, and silence: A comparison of relaxation techniques. Journal of Music Therapy, 37(1), 2-21. https://doi.org/10.1093/jmt/37.1.2

Roth, S. i Cohen, L. J. (1986). Approach, avoidance, and coping with stress. American Psychologist, 41(7), 813-819. https://doi.org/10.1037/0003-066X.41.7.813

Segal, Z. V., Williams, J. M. G. i Teasdale, J. D. (2002). Mindfulness based cognitive therapy for depression - A new approach to preventing relapse. Guilford Press.

Sekaran, U. (2003). Research methods for business: A skill building approach. John Wiley \& Sons.

Shapiro, S. L., Brown, S. K., Thoresen, C. i Plante, T. G. (2010). The moderation of Mindfulness-based stress reduction effects by trait mindfulness: Results from a randomized controlled trial. Clinical Psychology, 67, 267-277. https://doi.org/10.1002/ jclp.20761

Shapiro, S. L., Carlson, L. E., Astin, J. A. i Freedman, B. (2006). Mechanisms of mindfulness. Journal of Clinical Psychology, 62(3), 373-386. https://doi.org/10.1002/jclp.20237

Sheppes, G. i Gross, J. J. (2011). Is timing everything? Temporal considerations in emotion regulation. Personality and Social Psychology Review, 15(4), 319-331. https://doi.org/10.1177/1088868310395778

Thoondee, K. D. i Oikonomou, A. (2017, July). Using virtual reality to reduce stress at work. Paper presented at 2017 Computing Conference, London, UK. https://doi.org/10.1109/ SAI.2017.8252142

Tomlinson, E. R., Yousaf, O., Vittersø, A. D. i Jones, L. (2018). Sispositional mindfulness and psychological health: A systematic review. Mindfulness, 9(1), 23-43. https://doi.org/10.1007/s12671-017-0762-6 
Vøllestad, J., Sivertsen, B. i Nielsen, G. H. (2011). Mindfulness-based stress reduction for patients with anxiety disorders: Evaluation in a randomized controlled trial. Behaviour Research and Therapy, 49(4), 281-288. https://doi.org/:10.1016/j.brat.2011.01.007

Walker, D. L. i Carrive, P. (2003). Role of the ventrolateral periaqueductal gray neurons in the behavioral and cardiovascular responses to contextual conditioned fear and post stress recovery. Neuroscience, 116, 897-912. https://doi.org/10.1016/s0306-4522(02) 00744-3

Western, P. J. i Patrick, J. M. (1988). Effects of focusing attention on breathing with and without apparatus on the face. Respiration Physiology, 72(1), 123-130. https://doi.org: 10.1016/0034-5687(88)90084-9

Wolgast, M., Lundh, L. G. i Viborg, G. (2011). Cognitive reappraisal and acceptance: An experimental comparison of two emotion regulation strategies. Behaviour Research and Therapy, 49, 858-866. https://doi.org/10.1016/j.brat.2011.09.011

\title{
Effectiveness of Mindfulness Techniques and Virtual Reality in Reducing Stress
}

\begin{abstract}
Mindfulness and virtual reality (VR) have recently been growing popular as stress-coping strategies. Despite that, there is not enough research that compared these techniques or has taken personality traits into account. This study aimed to examine the effectiveness of mindfulness and virtual reality techniques for immediate stress-relief and to examine the efficacy of techniques depending on individual differences in trait anxiety and dispositional mindfulness. The study was conducted on 122 participants. One VR animation was used to induce fear of height in participants, while VR nature animation and mindfulness audiotape were used to relax participants. Subjective and physiological indices of anxiety were measured through electrodermal activity. Five-Facet Mindfulness Questionnaire and Questionnaire of Approach and Avoidance Motivation were used to collect information about dispositional mindfulness and trait anxiety. Results suggest that the participants estimated that they were significantly more relaxed after the nature animation and the mindfulness audiotape compared to the control group, although the physiological measures did not follow these results. Furthermore, mindfulness audiotape was most effective in highly anxious and low mindfulness individuals, while in the case of nature animation these dispositions did not play a significant role. This study indicates the possibility to use short mindfulness and virtual reality techniques in stress-reduction as well as the importance of personality traits in their effectiveness.
\end{abstract}

Keywords: mindfulness, virtual reality, anxiety, electrodermal activity

Primljeno: 10. 4. 2020. 